\title{
A Fresh Approach to the Ex Turpi Causa and 'Clean Hands' Maxims*
}

\author{
Gilbert Kodilinye
}

In Tinsley v. Milligan ${ }^{1}$ the Court of Appeal has recently attempted to redefine the scope of the maxims ex turpi causa non oritur actio and 'he who comes to equity must come with clean hands' in the context of resulting and constructive trusts. In this case the plaintiff and the defendant entered into a joint business enterprise from the proceeds of which they purchased a house in which they lived together in a lesbian relationship. The legal title was conveyed into the sole name of the plaintiff, but on the understanding that the parties should each be entitled to a beneficial half-share. This entitlement was not embodied in any contract but arose "by reason of [their] equal contribution to the purchase price and in accordance with the declared intentions of both parties." Soon after the purchase the parties quarrelled and the plaintiff moved out, leaving the defendant in occupation. Subsequently the plaintiff sought possession of the house, asserting her legal title. The defendant counterclaimed for an order of sale and for a declaration that the property was held by the plaintiff upon trust for the two of them in equal shares.

The sole issue before the Court of Appeal was whether the defendant's counterclaim was barred on account of the fact that, over a period of years, the defendant, with the concurrence of the plaintiff, had made false claims to the Department of Social Security for various benefits, and that their declared purpose for having the legal title in the sole name of the plaintiff was to assist in the fraud by misrepresenting to the DSS that the defendant had no stake in the property and that she was only the plaintiff's lodger. ${ }^{2}$ The Court of Appeal held by a majority, affirming the decision of the trial judge, that the defendant's claim was not barred by the ex turpi causa or 'clean hands' maxims, since, notwithstanding that the purpose of defrauding the DSS was illegal conduct of which the court should take notice, to refuse to grant relief to the defendant would be to deprive the defendant of her own property and to give it to the plaintiff who was equally implicated in the fraud.

\footnotetext{
* Senior Lecturer in Law, University of the West Indies, Cave Hill Campus, Barbados.
}

1. [1992] 2 W.L.R. 508. See J. Martin, [1992] Conv. 158.

2. It is interesting that no attempt was made to categorise the parties' lesbian relationship as immoral conduct barring a claim in equity. 
The actual decision in the case is unremarkable, but the main interest lies in the reasoning of the three Lords Justices, whose judgments contain the most comprehensive discussion yet of the modern scope and extent of the ex turpi causa and 'clean hands' maxims and of their relationship with one another, with particular reference to claims to beneficial interests under resulting or constructive trusts.

An attempt will be made in this article to identify the modern approach to the application of the maxims with reference to recent decisions of the Court of Appeal.

\section{Illegality at common law}

As Kerr LJ stated in Euro-Diam Ltd. v. Bathurst, "the courts will not assist a plaintiff who has been guilty of illegal or immoral conduct of which the courts should take notice." It is elementary law that a court will not enforce a contract or arrangement which is tainted with illegality (ex turpi causa non oritur actio); and that where money or property has been transferred under an illegal agreement, the court will not assist the transferor to recover it from the transferee (in pari delicto, potior est conditio defendentis (or possidentis). To this latter maxim there are three well-established exceptions where the court will permit recovery: (i) where the parties are not in pari delicto (i.e., where the transferor is shown to be less blameworthy than the transferee); (ii) where the transferor repents of the illegal purpose before it has been carried out (the locus poenitentiae principle); ${ }^{4}$ and (iii) where the plaintiff transferor can assert his title to the property without having to disclose the illegal purpose.

Of these exceptions only the third was in issue in Tinsley v. Milligan and in a number of other recent cases. Before considering the application of the exception, however, it is necessary to consider the juridical basis of the ex turpi causa and in pari delicto maxims as interpreted in recent decisions.

\section{Public policy}

It is clear that the application of the ex turpi causa and in pari delicto defences involves issues of public policy, and that such application depends on the circumstances of the particular case. The modern view, which has been called a "flexible approach", 5 was explained by Bingham LJ in Saunders v. Edwards: ${ }^{6}$

"Where issues of illegality are raised, the courts have to steer a middle course between two unacceptable positions. On the one hand it is unacceptable that any court of law should aid or lend its authority to a party seeking to pursue

3. [1988] 2 All E.R. 23, at p. 28.

4. See the discussions in G. Kodilinye, [1980] Anglo-American L.R. 28 and J. Martin [1992] Conv. 158.

5. Tinsley v. Milligan, supra n. 1 , at p. 513.

6. [1987] 2 All E.R. 651, at pp. 665,666 (C.A.). 
or enforce an object or agreement which the law prohibits. On the other hand, it is unacceptable that the court should on the first indication of unlawfulness affecting any aspect of a transaction, draw up its skirts and refuse all assistance to the plaintiff, no matter how serious his loss or how disproportionate his loss to the unlawfulness of his conduct."

His Lordship also pointed out? that "the courts have tended to adopt a pragmatic approach to these problems, seeking where possible to see that genuine wrongs are righted, so long as the court does not thereby promote or countenance a nefarious object or bargain which it is bound to condemn. Where the plaintiff's action in truth arises directly ex turpi causa, he is likely to fail. ... Where the plaintiff has suffered a genuine wrong, to which allegedly unlawful conduct is incidental, he is likely to succeed."

\section{The 'public conscience test'}

Another modern rationalisation of the courts' approach to the illegality defence, which was first put forward by Hutchinson $\mathrm{J}$ in Thackwell v. Barclays Bank, ${ }^{8}$ has become known as the 'public conscience test'. The learned judge had suggested in that case that the court should seek to answer two questions: "(1) whether there had been an illegality of which the court should take notice, and (2) whether in all the circumstances it would be an affront to the public conscience if, by affording him the relief sought, the court was seen to be indirectly assisting or encouraging the plaintiff in his criminal act."

The 'public conscience test' has been approved by the Court of Appeal in at least three subsequent cases. ${ }^{9}$ One of these is Saunders v. Edwards, ${ }^{10}$ where the defendant sold the lease of a flat to the plaintiffs for $£ 45,000$, after fraudulently misrepresenting that the flat contained a roof garden. The trial judge awarded damages to the plaintiffs for the tort of deceit, but the defendant appealed on the ground, inter alia, that the plaintiffs' claim required them to rely on a fraudulent apportionment in the contract of sale (which they had instigated) whereby the fixtures and fittings had been overvalued and the flat itself undervalued - an unlawful scheme to reduce the amount of stamp duty payable to the Revenue on the conveyance of the flat. The defendant's appeal was dismissed by the Court of Appeal. Kerr LJ emphasised ${ }^{11}$ that the plaintiffs' action was not to enforce the contract of sale nor to seek any relief in connection with it, but was a claim in tort based on the defendant's fraudulent misrepresentation. The case had, therefore, to be distinguished from the well-known decision in Alexander v. Rayson, ${ }^{12}$ which

\section{Ibid..}

8. [1986]All E.R. 676, at p. 687 .

9. Saunders v. Edwards [1987] 2 All E.R. 651; Euro-Diam Ltd. v. Bathurst [1988] 2 All E.R. 23; Howard v. Shirlstar Container Transpart Ltd. [1990] 3 All E.R. 366.

10. [1987] 2 All E.R. 65I.

11. At p. 659.

12. [1936] I K.B. 169. 
was an action in contract to recover arrears of rent under a lease designed to defraud the Revenue. In Kerr LJ's view, the relevance of the ex turpi causa defence lay mainly in the field of contractual claims and only rarely in tort. There were no rigid rules for or against the application of the defence and, being based on public policy, it depended very much on the circumstances of the individual case, including the conduct and relative moral culpability of the parties. Nicholls LJ took a similar approach ${ }^{13}$ to that of Kerr LJ, adding that the 'public conscience test' propounded in Thackwell v. Barclays Bank was a useful and valuable one and should be applied in the instant case. It is not clear whether Nicholls LJ regarded the 'public conscience test' as being restricted to actions in tort, or whether he regarded it as applicable also to contractual and other claims. As far as the present action was concerned, all three Lords Justices were in agreement that the defendant's moral culpability greatly outweighed that of the plaintiffs, and that the appeal should be dismissed.

Another recent case in which the 'public conscience test' was applied is Howard v. Shirlstar Container Transport Ltd. ${ }^{14}$ Here the defendants wished to repossess an aircraft which had been hired out for private use in Nigeria, the hire instalments being in arrears. They engaged the plaintiff, a qualified pilot, to fly the aircraft out of Nigeria, contracting to pay him half of the agreed fee as soon as the aircraft had been removed from Nigerian airspace, and the balance one month thereafter. Being informed that his life might be in danger, the plaintiff flew the aircraft out of Nigeria without obtaining air traffic control clearance, which was a breach of Nigerian law. One of the issues in the case was whether the plaintiff was barred from recovering the payment due in England on account of the illegal performance of the contract in Nigeria.

Staughton LJ considered ${ }^{15}$ that prima facie the plaintiff's claim would be unenforceable in an English court. "To take off from a Nigerian airport in breach of regulations was central to his performance of the contract, as it was in fact performed. It was in no sense an incidental illegality." However, this was clearly a case where, despite the illegal performance, "the plaintiff's claim should not fail, because the conscience of the court is not affronted." The factor which led to this conclusion was that the plaintiff committed the offence in order "to free himself ... from pressing danger."

The 'public conscience test' has not received unanimous acceptance, however. In Pitts v. Hunt, ${ }^{16}$ Dillon LJ considered ${ }^{17}$ the test to be very difficult to apply, since the public conscience might well be affected by matters of an emotional or political nature which the court ought not to be required to take into account. Furthermore, an appeal to the 'public conscience' would be likely to lead to a graph of illegalities

17. At p. 362. 
according to moral turpitude, in which it would be necessary to distinguish between serious and non-serious illegality, between the former categories of felonies and misdemeanours, between offences punishable by imprisonment and those which were not, and so on. His Lordship preferred the dichotomy between cases where the plaintiff's action arises directly from the illegality and those where he suffers a wrong to which the illegality is merely incidental - a distinction applied by Bingham LJ in Saunders v. Edwards. ${ }^{18}$ Thus the latter decision could be rationalised on the basis that the unlawful apportionment was merely incidental to the plaintiff's claim, which arose not from the apportionment but from the defendant's fraudulent misrepresentation.

\section{The 'clean hands' principle}

In Tinsley v. Milligan the plaintiff contended that the case was governed by the maxim that 'he who comes to equity must come with clean hands'. On this argument, once the court finds that property has been conveyed into the name of one party for a fraudulent purpose, the court will not enforce a trust in favour of the other party since his hands are 'unclean'. In such circumstances, the plaintiff argued, the 'public conscience test' had no application and there was no scope for any balancing exercise involving the relative moral culpability of the parties.

The leading modern examples of the application of the 'clean hands' maxim are Gascoigne v. Gascoigne ${ }^{19}$ and Tinker v. Tinker. ${ }^{20}$ In Gascoigne, a husband who was in debt to moneylenders took a lease of land in his wife's name and built a house on it at his own expense. His sole reason for putting the property in the wife's name was to protect it from his creditors. When the parties became estranged the husband sought a declaration that the wife held the lease as trustee for him. It was held that the husband would not be permitted to rebut the presumption of advancement which arose in favour of the wife by setting up his fraudulent purpose.

In Tinker v. Tinker, ${ }^{21}$ a husband who, unlike in Gascoigne, was not in debt at the time, transferred the matrimonial home into his wife's name. His purpose in doing so was to protect it from possible future creditors, in case the business on which he had recently embarked should fail. The Court of Appeal held that the husband could not rebut the presumption of advancement by asserting that his intention was to put the property out of reach of possible creditors. Lord Denning MR explained the position thus: ${ }^{22}$

"I am quite clear that the husband cannot have it both ways. So he is on the horns of a dilemma. He cannot say that the house is his own and, at one

18. [1987] 2 All E.R. 651 (C.A.).

19. [1918] 1 K.B. 223 (D.C.).

20. [1970] 1 All E.R. 540 (C.A.).

21. Ibid.

22. Ibid., at p. 542. See also Maysels v. Maysels (1974) 45 D.L.R.. (3d) 337; Munro v. Morrison [1979] V.R. 83. 
and the same time, say that it is his wife's. As against his wife, he wants to say that it belongs to him. As against his creditors that it belongs to her. That simply will not do. Either it was conveyed to her for her own use absolutely; or it was conveyed to her as trustee for her husband. It must be one or the other. The presumption is that it was conveyed to her for her own use; and he does not rebut that presumption by saying that he only did it to defeat his creditors. I think that it belongs to her."

The Gascoigne and Tinker cases are thus authority for the proposition that a husband who voluntarily transfers property to his wife will not be able to rebut the presumption of advancement or gift by showing that his real intention in making the transfer was to defeat his creditors, for he "cannot be allowed to take advantage of his own dishonesty." ${ }^{23}$ In accordance with the principle 'let the estate lie where it falls', the husband will be unable to recover the property. A similar decision was Chettiar v. Chettiar, ${ }^{24}$ where a father had transferred rubber plantations in Malaya to his son in order to evade certain provisions of the Rubber Regulations of 1934. The father was not permitted to rebut the presumption of advancement by pleading his unlawful purpose.

Where a presumption of advancement applies, the position is thus clear; but what is the position where the transferor (as in Tinsley v. Milligan) is not seeking to rebut a presumption of advancement in the transferee's favour but is relying on a presumption of a resulting trust in his favour? If in such a case the estate is left to 'lie where it falls', it could be argued that the transferor should recover on the strength of his own equitable title which he can assert without disclosing the unlawful purpose. This reasoning was applied in a Canadian case, Gorog v. Kiss, ${ }^{25}$ where the plaintiffs, who were husband and wife, had transferred property to the defendant without consideration in order to defeat their creditors. The Ontario Court of Appeal held that the plaintiffs' action to recover the property succeeded since

"the plaintiffs did not have to rely on the illegal purpose in stating the facts giving rise to the presumption of a resulting trust, and establishing their right to the property unless the presumption was rebutted."26

As Professor D. W. Waters has explained, "the transferor has not needed to put his illegal purpose in evidence. It is of no significance if the transferee tells the court what the purpose was: the transferor is not relying on that purpose."27

\section{Ibid..}

24. [1962] A.C. 294 (P.C.).

25. (1977) 78 D.L.R. 690. See also Marks v. Marks (1974) 18 R.F.L. 323; Swick v. Swick (1979) 12 R.F.L. (2d) 252.

26. At p. 695 .

27. Law of Trusts, Studies in Current Law, 1975, p. 12. 
A second possibility is that to allow the estate to 'lie where it falls' means that the transferee will be able to rely on his legal title, as a court of equity will not permit the transferor, whose hands are unclean, to claim his equitable interest.

This approach was adopted by Ralph Gibson LJ in Tinsley v. Milligan. ${ }^{28}$ Some support for it can be found in Singh v. Ali, ${ }^{29}$ where Lord Denning took the view that where two persons conspire to effect a fraudulent or illegal purpose, and property is transferred in pursuance of that purpose, "the transferee, having obtained the property, can assert his title to it against all the world, not because he has any merit of his own, but because there is no one who can assert a better title to it. The court does not confiscate the property because of the illegality - it has no power to do so - so it says, in the words of Lord Eldon: 'Let the estate lie where it falls'." 30

A third possibility is that the presumption of resulting trust can be rebutted by evidence of the actual intention of the parties, whether that intention is to defraud creditors or the revenue or some other purpose. In Cantor v. Cox $x^{31} \mathbf{C}$, a businessman, and $\mathbf{T}$, a woman with whom he was cohabiting, purchased a house which, in order to protect it from possible creditors of $\mathbf{C}$, was conveyed into the sole name of $\mathbf{T}$. After $\mathbf{T}$ 's death $\mathbf{C}$ claimed to be entitled to a beneficial interest in the property on the basis of a resulting trust arising from his contribution to the purchase price. Plowman VC held that C's claim failed. The presumption of a resulting trust had been rebutted by evidence of the actual intention of the parties, which was to put the property out of the reach of possible creditors of $\mathbf{C}$. It is submitted, with respect, that this reasoning is unacceptable, for the court is in effect permitting the transferee to set up the fraudulent purpose in order to rebut the presumption of resulting trust. Since it is well settled that a transferor cannot rebut a presumption of advancement by giving evidence of an unlawful intention, it cannot be good law to permit a transferee to rebut a presumption of resulting trust by such evidence. Such a 'double standard' would be clearly contrary to justice and equity.

\section{The judgments in Tinsley v. Milligan}

In Tinsley, Nicholls and Lloyd LJJ reached the same conclusion though by somewhat different reasoning, whilst Ralph Gibson LJ dissented.

Nicholls LJ considered that cases such as Tinker v. Tinker ${ }^{32}$ and Chettiar v. Chettiar ${ }^{33}$ should not be interpreted as laying down an immutable rule "that in every instance where a transfer of property is made for an illegal or dishonest purpose, and that purpose is carried into effect, the transferor cannot thereafter

28. [1992] 2 W.L.R. 508, at p. 530.

29. [1960] A.C. 167.

30. At p. 176.

31. (1975) 239 E.G. 121.

32. [1970] All E.R. 540 (C.A.).

33. [1962] A.C. 294 (P.C.). 
look to the court for assistance in obtaining a transfer, whatever the circumstances", ${ }^{34}$ nor, in his view, did they establish any special principle peculiar to the Law of Trusts. His Lordship considered that these were merely examples of cases in which, in particular circumstances, the court decided that to grant relief to the plaintiff would have been an affront to the public conscience.

It is submitted with respect that it is incorrect to analyse the Tinker line of cases in this way. They were actions in equity where the court was being asked to admit evidence in rebuttal of an equitable presumption of advancement, and where the 'clean hands' maxim, not the common law ex turpi causa principle, was being applied. It may well be that in this area the streams of common law and equity now run in the same channel and that their waters have become mixed, but it is only very recently, and certainly subsequently to the Tinker and Chettiar decisions, that this mingling has occurred. If the 'public conscience test', first enunciated in actions in tort, does apply to the equity cases, then this application may need the sanction of the House of Lords or the Privy Council at some future date. That is not to suggest that it would be undesirable to apply such a test in equity cases such as Tinsley v. Milligan. On the contrary, such a test is sufficiently flexible to enable the court to consider all the relevant circumstances, including the relative blameworthiness of the parties, the degree of unlawfulness of the purpose and the extent to which it has been, or could be, carried out, the value of the property and the possible loss to the revenue, and any other matters which the court ought to take into account in deciding whether recovery should be permitted. ${ }^{35}$

Another main feature of Nicholls LJ's reasoning was what he called "the non-confiscation approach". As we have seen, in Singh v. Ali Lord Denning had stated that "the court does not confiscate the property because of the illegality - it has no power to do so - so it says, in the words of Lord Eldon: 'Let the estate lie where it falls'." 36 Nicholls $\mathrm{LJ}$ took the view that the 'non-confiscation' principle (which was the basis of the exception that a transferor may recover property transferred for an unlawful purpose if he can assert his legal title without having to disclose that purpose) was as applicable to equitable interests as it was to legal estates. Thus, on the facts in Tinsley, "if the court will have regard to and will enforce the plaintiff's legal title and will disregard the fraudulent purpose for which that title was vested in her alone, surely the court must also have regard to the equitable title vested in the defendant and give her like assistance." 37

Thus Nicholls LJ held that the defendant's counterclaim succeeded both on the above ground and on the ground that, far from it being an affront to the 'public conscience' to grant relief, it would be an affront to the 'public conscience' not to do so; for to refuse to grant relief to the defendant would be to deprive her of her own property, which would be a disproportionate penalty. ${ }^{38}$

34. [1992] 2 W.L.R., at pp. 518, 519.

35. See Scott on Trusts 3rd edn., Vol. V, para. 422.5.

36. See nn. 29 and 30 , supra.

37. At pp. 519,520 .

38. [1992] 2 W.L.R., at p. 516. 
Lloyd $\mathrm{L} J$ reached the same conclusion as Nicholls $\mathrm{LJ}$, but by a slightly different route. ${ }^{39}$ In his view, the defendant did not need to rely on the illegal purpose to establish the common intention (i.e., that the house was to be held on behalf of both parties in equal shares) on which her claim rested. Although the defendant was bound to answer in cross-examination that the purpose for putting the house in the plaintiff's name rather than in joint names was to deceive the DSS, this illegal purpose did not taint the defendant's claim, as it was "purely collateral or incidental". It was "relevant only as a matter of history." His Lordship was not convinced that it was necessary to create a separate category of 'non-confiscation' cases. In his opinion, it was preferable to regard them as being cases where the plaintiff was not seeking to enforce, or found his claim on, an illegal transaction. He then went on to say that there was a second question to be asked, namely, whether, despite the finding that the claim was not based on an illegal transaction, the court should nevertheless refuse to entertain the claim on overriding grounds of public policy. Lloyd LJ found the 'public conscience' test imprecise and difficult to apply, but he considered that he was bound by recent decisions which had approved it. In the instant case, it would not, in his opinion, affront the 'public conscience' or shock the ordinary citizen for the court to entertain the defendant's claim to a beneficial half-share in the house. As for the Tinker principle, Lloyd LJ saw no reason why the court should not, in its equitable jurisdiction, adopt the more flexible attitude shown by the common law. In this connection, it is noteworthy that Nicholls LJ had also emphasised that the 'clean hands' maxim was to be applied no less flexibly than its common law counterpart, and that it could not be that equity, "rooted in giving relief against unconscionable conduct, shuts its eyes and applies a rigid rule when the common law acts with its eyes wide open to all the circumstances." 40

Ralph Gibson LJ, dissenting, ${ }^{41}$ considered that the questions to be answered were: (i) whether the defendant's counterclaim was within the 'clean hands' principle as applied in cases such as Tinker; (ii) if it was, whether more recent cases had modified that principle. He answered the first question in the affirmative, considering that the arrangement between the plaintiff and the defendant, under which the plaintiff was to be apparently the sole owner of the house, was at least as much a dishonest plot on the part of the defendant as was that of the husband in Tinker's case. As for the second question, his Lordship took the view that recent cases in which more flexible criteria such as the 'public conscience' test had been applied were actions based not on any illegal contract or arrangement but on some tortious conduct to which the illegality was merely incidental. It could not be said that any of these cases were directed to any modification of the rule in Tinker's case. Ralph Gibson LJ referred to the deterrent effect of a strict application of the 
ex turpi causa and 'clean hands' maxims and considered that the latter principle should be applied in the instant case. His final point was that the plaintiff was entitled to rely on her legal estate under the 'non-confiscation' principle since "when the court refuses to enforce a contractual right, or an equitable right, it leaves the party who successfully raises the defence in possession of whatever legal rights he has in the subject-matter of the contract or arrangement, as in Gascoigne v. Gascoigne and Tinker v. Tinker."

It is respectfully submitted that although Ralph Gibson $\mathrm{LJ}$ was correct in his view that cases such as Thackwell, Saunders and Euro-Diam were actions in tort, and were not directed to modification of the equitable 'clean hands' maxim as applied in Tinker, it may well be desirable, as Nicholls and Lloyd LJJ suggested, that the new flexible approach in those cases should be applied to the equitable maxim. Quite apart from the need to balance the respective culpability of the parties, it is unsatisfactory that the rights of a transferor to claim a beneficial interest in property should depend upon whether a resulting trust (as in Gorog v. Kiss $^{42}$ and, indeed, in Tinsley) or an advancement (as in Tinker and Gascoigne ${ }^{43}$ is presumed. The result of this distinction is that, for example, a mother who pays for property and has it conveyed to her daughter in order to defraud the revenue may nevertheless claim a beneficial interest because a resulting trust in her favour is presumed and she is not driven to rely on the illegal purpose, whereas a father who does precisely the same with the same fraudulent intent will be barred because the presumption of advancement in the daughter's favour cannot be rebutted by evidence of the fraudulent purpose. Application of the flexible test in the Thackwell line of cases would make it unnecessary to consider whether a resulting trust or an advancement was to be presumed.

\section{Conclusion}

The judgments of Nicholls and Lloyd LJJ in Tinsley v. Milligan have emphasised the current judicial thinking as regards the application of the ex turpi causa and 'clean hands' maxims. It seems that the courts now see the two maxims not as separate principles but as expressions of the same broad principle, founded on public policy, that the court will not entertain an action in contract or tort or to establish an equitable right if to do so would be an affront to the public conscience. There is no rigid rule that where a contract or arrangement is tainted with illegality, the court will 'draw up its skirts' and refuse all relief, as has sometimes been suggested. Rather, the court should attempt a balancing exercise in which the relative blameworthiness and moral culpability of the parties is considered. The judgments also affirm the principle that where a claimant seeks recovery of property transferred under an unlawful agreement or arrangement he will be entitled to recovery if he can establish his title without having to disclose the unlawful purpose, and that this applies as much to an equitable as to a legal title. 